\title{
Phospholipase-A-independent damage caused by the colicin A lysis protein during its assembly into the inner and outer membranes of Escherichia coli
}

\author{
S. Peter Howard, ${ }^{1 *}$ Danièle Cavard ${ }^{2}$ and Claude Lazdunski ${ }^{2}$ \\ ${ }^{1}$ Memorial University of Newfoundland, St John's, Newfoundland, Canada A1B 3V6 \\ ${ }^{2}$ Centre National de la Recherche Scientifique, BP 71, F-13402 Marseille Cedex 9, France
}

(Received 28 June 1990; revised 29 August 1990; accepted 18 September 1990)

\begin{abstract}
The requirement for the activation of phospholipase $A$ by the colicin $A$ lysis protein (Cal) in the efficient release of colicin A by Escherichia coli cells containing colicin A plasmids was studied. In particular, we wished to determine if this activation is the primary effect of $\mathrm{Cal}$ or whether it reflects more generalized damage to the envelope caused by the presence of large quantities of this small acylated protein. $E$. coli tol $Q$ cells, which were shown to be leaky for periplasmic proteins, were transduced to pld $A$ and then transformed with the recombinant colicin A plasmid pKA. Both the pldA and pldA $A^{+}$strains released large quantities of colicin A following induction, indicating that in these cells phospholipase $A$ activation is not required for colicin release. This release was, however, still dependent on a functioning Cal protein. The assembly and processing of $\mathrm{Cal}$ in situ in the cell envelope was studied by combining pulse-chase labelling with isopycnic sucrose density gradient centrifugation of the cell membranes. Precursor Cal and lipid-modified precursor Cal were found in the inner membrane at early times of chase, and gave rise to mature Cal which accumulated in both the inner and outer membrane after further chase. The signal peptide was also visible on these gradients, and its distribution too was restricted to the inner membrane. Gradient centrifugation of envelopes of cells which were overproducing Cal resulted in very poor separation of the membranes. The results of these studies provide evidence that the colicin A lysis protein causes phospholipase A-independent alterations in the integrity of the $E$. coli envelope. These alterations are required for the breakdown of the permeability barrier leading to colicin export.
\end{abstract}

\section{Introduction}

Colicins are antibacterial protein toxins which are synthesized and exported during the SOS response of Escherichia coli cells which bear a colicin plasmid (de Graaf \& Oudega, 1986). The release of these toxic proteins has been shown in a number of cases to require the action of small lipoproteins (lysis or release proteins) which are also encoded by the plasmid-borne colicin operons (Pugsley \& Schwartz, 1983; Watson et al., 1986; Cavard et al., 1985; Hakkaart et al., 1981). The lysis proteins cause a partial decrease in the optical density of the producing culture called quasi-lysis which accompanies the slow release of the colicin to the environment (de Graaf \& Oudega, 1986).

It has been well established that the induction of the lysis protein causes activation of the outer membrane phospholipase $\mathrm{A}$ and that this activation is required for both efficient quasi-lysis and the export of the colicin

Abbreviation: Cal, colicin A lysis protein.
(Cavard et al., 1987; Pugsley \& Schwartz, 1984; Luirink et al., 1986). Since this phospholipase is an outer membrane protein, however, it remained possible that its activation is required only for the breach of the permeability barrier of this membrane. According to this hypothesis, the release of the phospholipase $\mathrm{A}$ from its tightly regulated state is part of a more generalized disorganization of the structure of the envelope caused by the lysis protein. Its activation would thus represent a necessary but not sufficient step in quasi-lysis and the export of the colicin.

Using colicin A release as a model system, we have tested this hypothesis by studying the requirement for phospholipase A activation for colicin release in tol cells. The tol group of genes was first identified as a result of mutations which allowed $E$. coli cells to become tolerant to the presence of various bacteriophages and colicins (Sun \& Webster, 1987; Nagel del Zwaig \& Luria, 1967; Nomura \& Witten, 1967). The tol mutants are defective in part of a multicomponent uptake system which is involved in the transport of these substances across the 
envelope of target cells and in this and other respects they are similar to the ton mutants, which are part of a more well-defined uptake system with different specificity (Heller et al., 1988). One of the earliest phenotypes of the tol mutations to be recognized was that of periplasmic leakiness, which apparently results from the disturbances in the integrity of the outer membrane which the mutations cause (Bernstein et al., 1972; Lazzaroni \& Portalier, 1981). Thus mutations in tolA or tolB were shown to be leaky for a number of periplasmic enzymes (Fognini-Lefebvre et al., 1987). We reasoned that examination of colicin export in tol cells would allow an otherwise difficult distinction between functions required for passage of colicin $A$ across the inner membrane and functions required for passage across the outer membrane. In addition, we examined the localization and assembly of the colicin A lysis protein $(\mathrm{Cal})$ in the envelope of induced cells, in an attempt to determine the site within the envelope at which it performs its permeabilizing function.

The results indicate that the activation of phospholipase $\mathrm{A}$ by $\mathrm{Cal}$ is required only for the disruption of the outer-membrane permeability barrier. In addition, gradient analysis of the envelopes of induced cells showed that $\mathrm{Cal}$ accumulates in both the inner and outer membranes of the cell, and that when overexpressed it prevents the separation of the inner and outer membranes by this procedure.

\section{Methods}

Bacterial strains and plasmids. The E. coli $\mathrm{K} 12$ strains CBM degP41 (=W3110 pldA $\operatorname{deg}$ P4I) (Cavard et al., 1989a), GMI [ara $\Delta$ (lac-pro) thi ( $F^{\prime}$ lac-pro)] and TPS13 (GM1, tolQ) (Sun \& Webster, 1986) were used. A pldA derivative of TPS 13 was constructed via P1 transduction as previously described (Cavard et al., 1989c). The plasmids pKA and pS16 (Howard et al., 1989), and pAT1 (Cavard et al., 1989b) were transformed into these strains as required.

Growth conditions. Strains were routinely grown at $37^{\circ} \mathrm{C}$ with good aeration in LB medium with or without $50 \mathrm{mg}$ ampicillin $\mathrm{ml}^{-1}$. For radiolabelling, they were grown in $\mathrm{M} 9$ medium supplemented with thiamin $\left(1 \mathrm{mg} \mathrm{ml}^{-1}\right), 0.4 \%$ glycerol, and $0.5 \%$ methionine assay medium (Difco). For induction of the colicin A operon, mitomycin C (Sigma) was used at a concentration of $300 \mathrm{ng} \mathrm{m}^{-1}$.

Radiolabelling, cell fractionation and membrane isolation. Cultures were grown in $\mathrm{M} 9$ medium and induced with mitomycin $\mathrm{C}$ at an $\mathrm{OD}_{600}$ of 1.0 . After $45 \mathrm{~min}$, the cells were labelled with $\left[{ }^{35}\right.$ S $]$ methionine $\left(370 \mathrm{kBq} \mathrm{ml}^{-1}, \sim 50000 \mathrm{GBq} \mathrm{mmol}^{-1}\right)$ for $5 \mathrm{~min}$ and chased with unlabelled methionine $\left(0.5 \mathrm{mg} \mathrm{ml}^{-1}\right)$. After various periods of chase as indicated in the Figures, $20 \mathrm{ml}$ volumes of the cultures were rapidly cooled on wet ice and disrupted by passage through a precooled French pressure cell at $69 \mathrm{MPa}$. The envelopes were then isolated and centrifuged through sucrose density gradients exactly as described by Ishidate et al. (1986). This resulted in the separation of the membrane peaks designated by these authors as $I M, B, O M_{L}$ and $O_{M}$. The gradients were then fractionated and the radioactive profile deter- mined by scintillation counting while the density profile was determined using a refractometer.

General methods. For analysis of proteins released to the culture medium upon induction of the colicin A operon, samples were taken from induced cultures and centrifuged for $1 \mathrm{~min}$ at $15000 \mathrm{~g}$. Cell pellets and supernatants were dissolved in electrophoresis sample buffer, and volumes representing an equal amount of the original culture were analysed by SDS-PAGE $(10 \%, w / v$, acrylamide $)$. Cal and other proteins in the sucrose density gradient fractions were analysed by electrophoresis on 11-15\% urea/SDS-PAGE gels which were treated for fluorography as previously described (Cavard et al., 1987). $\beta$-Lactamase activity was measured using the chromogenic substrate PADAC (Calbiochem) (Howard \& Buckley, 1985). When necessary for these assays, cells were disrupted via lysozyme/EDTA treatment followed by resuspension in cold distilled water (Yamato et al., 1975).

\section{Results}

\section{Cells containing the tolQ mutation are periplasmic leaky}

During recent studies on the cellular components required for the uptake of colicin $A$, we examined the localization and assembly of tolQ, one of the four identified tol gene products (Bourdineaud et al., 1989). Here, we examined tolQ mutants for periplasmic leakiness by growing the cells in LB medium and directly examining the protein content of the culture supernatants by SDS-PAGE (Fig. 1). This analysis showed that a characteristic subset of proteins was released from the tol $Q$ cells which were not found in the supernatants of the wild-type cells. In order to verify that periplasmic proteins were released and to quantify the extent of this leakiness, we transformed these cells with pBR322 and then assayed the cellular and extracellular contents for the activity of the periplasmic enzyme $\beta$-lactamase. As seen in Table 1 , more than $70 \%$ of the total $\beta$-lactamase produced by the tol $Q$ cells was released to the culture supernatant whereas less than $5 \%$ of that produced by wild-type cells was released. These experiments showed that, as for the tolA and tolB mutants (Fognini-Lefebvre et al., 1987), defects in the tolQ gene result in disturbances in the integrity of the cell envelope which render it leaky to proteins normally retained in the periplasmic space.

\section{Cells containing the tolQ mutation do not require activation of phospholipase $A$ for colicin release}

We next compared tol $Q$ and wild-type bacteria containing the plasmid pKA, which encodes the colicin A operon, with respect to the requirement for phospholipase A activation for the release of colicin A. A pldA mutation was introduced into the tolQ strain by $\mathrm{P} 1$ transduction and the strains grown and induced with 


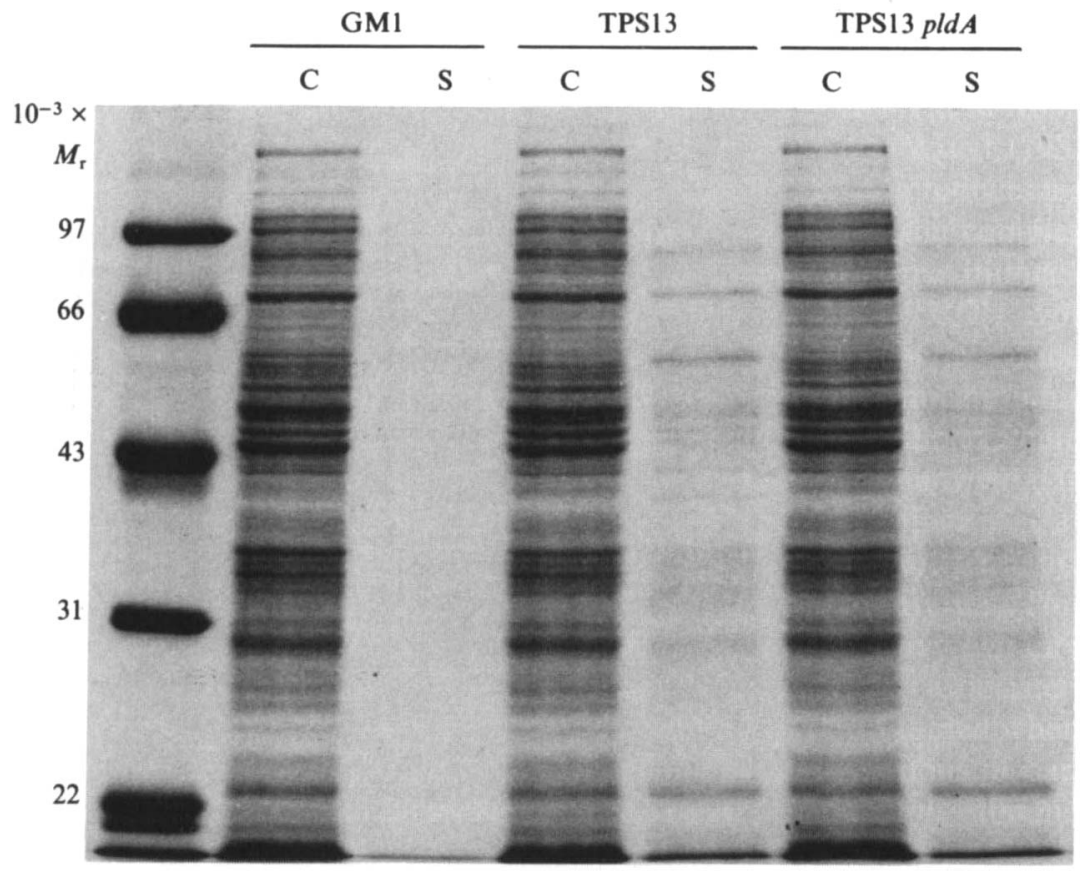

Fig. 1. Cells containing the tol $Q$ mutation are leaky. GM1, TPS 13 and TPS 13 pldA cultures were grown to late exponential phase in LB medium and cell (C) and culture supernatant (S) fractions were electrophoresed on a $10 \%$ SDS-PAGE gel which was stained with Coomassie blue. The sizes of the standard proteins are indicated on the left.
Table 1. tolQ cells release large amounts of $\beta$-lactamase to the culture supernatant

\begin{tabular}{lcr}
\hline \hline & \multicolumn{2}{c}{ Activity* } \\
\cline { 2 - 3 } \multicolumn{1}{c}{ Strain } & Cells & $\begin{array}{c}\text { Culture } \\
\text { supernatant }\end{array}$ \\
\hline GM1(pBR322) & $80.6(95 \cdot 2)$ & $4.0(4.8)$ \\
TPS13(pBR322) & $11 \cdot 8(29 \cdot 3)$ & $28.5(70 \cdot 7)$ \\
TPS13 pldA(pBR322) & $23.8(28.5)$ & $59.5(71.5)$ \\
\hline \hline
\end{tabular}

* Units are nmol substrate (PADAC, Calbiochem) hydrolysed min $^{-1}$ per $\mathrm{OD}_{600}$ unit of the original culture at $22^{\circ} \mathrm{C}$. Percentage values are shown in parentheses.

mitomycin C. The quasi-lysis curve and SDS-PAGE profiles of the cells and culture supernatants are shown in Fig. 2. It can be seen that both tol $Q$ and pld A tol $Q$ cells underwent quasi-lysis and released colicin $\mathrm{A}$ in a similar manner to the wild-type. Samples from uninduced cells were very similar to those shown in Fig. 1, and the identification of colicin $\mathrm{A}$ as shown in the Figure was verified by immunoblotting (data not shown). This result is in marked contrast to the effect of the pldA mutation on cells which do not also contain a tolQ mutation, in which both quasi-lysis and the release of colicin are severely attenuated for colicin A and all other colicins so far examined (Cavard et al., 1987; Pugsley \& Schwartz, 1984; Luirink et al., 1986). Despite this difference, we found that as expected the induction of Cal caused the accumulation of lysophospholipids in the tol $Q$ cells, but not in the tolQ pldA strain (data not shown).

Although it seemed unlikely, the finding that tol $Q$ cells no longer required the activation of phospholipase $A$ for colicin A release also left open the possibility that the cells no longer required the $\mathrm{Cal}$ protein for this function either. Indeed, given the leakage of periplasmic enzymes observed in tol $Q$ cells, this would have been expected if the colicin protein could reach the periplasmic space via the normal protein translocation machinery of the cell, as has been proposed for colicin El (Yamada et al., 1982). In order to rule out this possibility, the $\operatorname{tol} Q$ and tol $Q$ pld $A$ cells were also transformed with the plasmid pS16. This plasmid is similar to pKA except that it encodes a truncated $\mathrm{Cal}$ protein which cannot be lipid modified and processed normally and is thus inactive in colicin release (Howard et al., 1989). The cells containing this plasmid were induced with mitomycin $\mathrm{C}$ and examined with respect to quasi-lysis and colicin $\mathrm{A}$ release as before (Fig. 3). In each case, irrespective of the presence or absence of the tolQ mutation, the absence of a functional Cal protein abolished quasi-lysis and resulted in the accumulation of the majority of the colicin within the cells rather than in the culture supernatant. It should be noted that although none of the cells containing $\mathrm{pS} 16$ released large amounts of colicin A, the tol $Q$ pld $A$ cells did release more of both the colicin and other proteins from the cell than either tol $Q$ or wild-type cells did, perhaps reflecting an increase in the fragility of the envelope of the double mutant. 


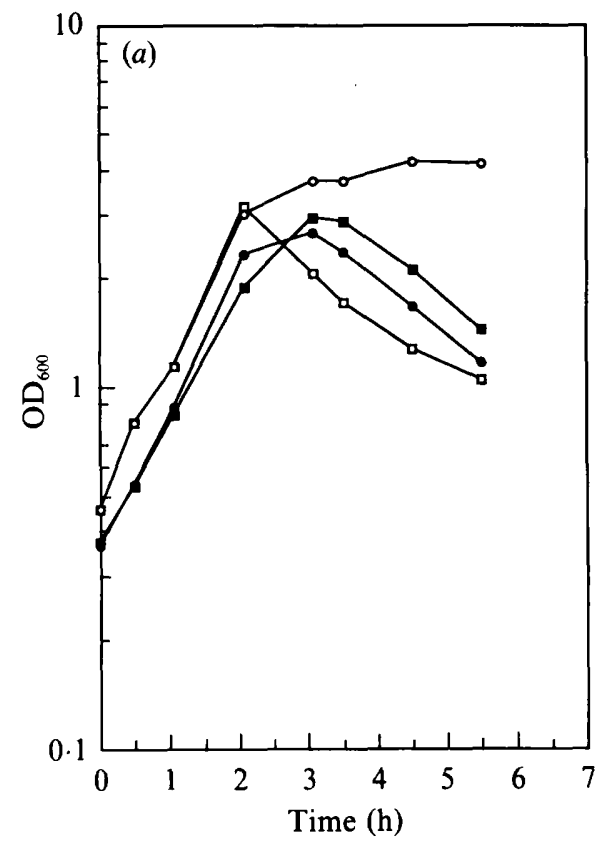

(b)

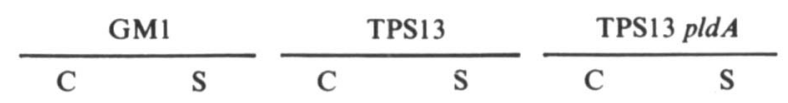

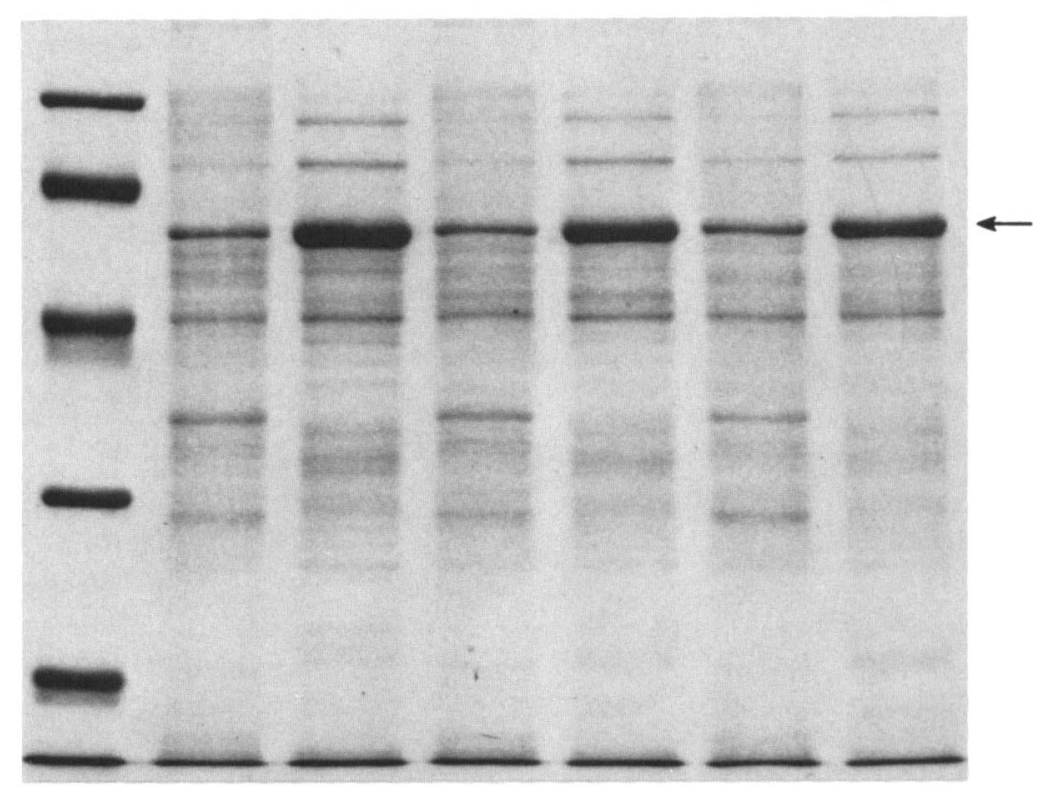

Fig. 2. Quasi-lysis and colicin A release occur normally in tolQ pldA cells. GM1, TPS13 and TPS13 pldA cells containing pKA were induced at an $\mathrm{OD}_{600}$ of 1 with mitomycin $\mathrm{C}$. (a) The $\mathrm{OD}_{600}$ of the cultures was monitored and plotted against the time of incubation at $37^{\circ} \mathrm{C}$. O, Control cells of GMl(pKA); $\square$, induced GM1(pKA) cells; $\bigcirc$, induced TPS13(pKA) cells; $\mathbf{\square}$, induced TPS13 pldA(pKA) cells. (b) After $5 \mathrm{~h}$ of induction, cell (C) and culture supernatant (S) samples were analysed by SDS-PAGE. The Coomassie blue stained gel is shown. The sizes of the standard proteins are as indicated in the legend to Fig. 1. The position of colicin $\mathrm{A}$ is indicated with an arrow.

(b)
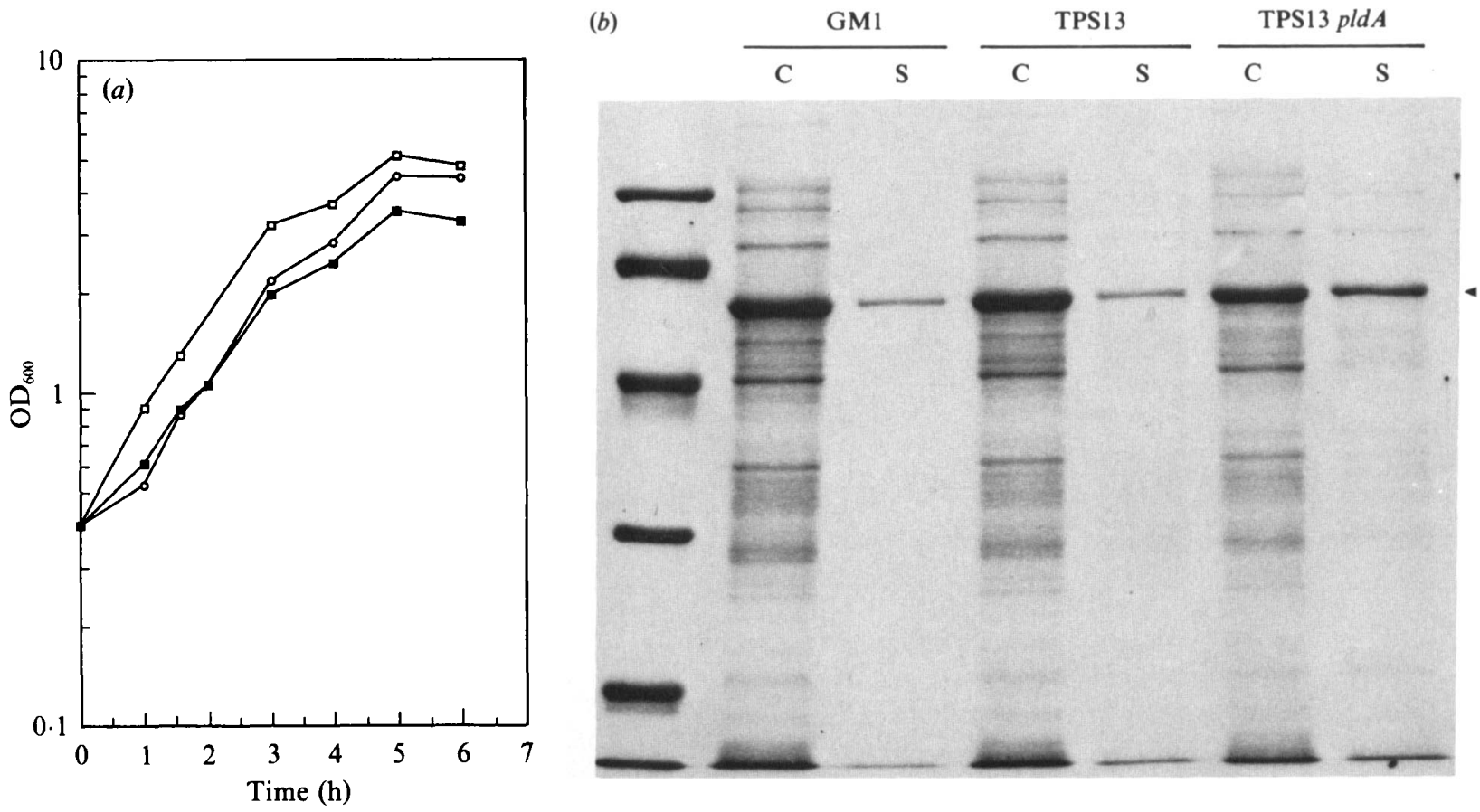

Fig. 3. Quasi-lysis and colicin A release do not occur in tolQ pldA cells which synthesize an inactive colicin A lysis protein. GM1, TPS13 and TPS13 pldA cells containing pS16 were induced with mitomycin $\mathrm{C}$ at an $\mathrm{OD}_{600}$ of 1 . (a) $\mathrm{OD}_{600}$ versus time: $\square$, induced GM1(pS16) cells; $O$, induced TPS13(pS16) cells; $\square$, induced TPS13 pldA(pS16) cells. (b) Samples of the cells (C) and culture supernatants (S) were analysed by SDS-PAGE. The Coomassie blue stained gel is shown. The sizes of the standard proteins are as indicated in the legend to Fig. 1. The position of colicin $A$ is indicated with an arrow. 

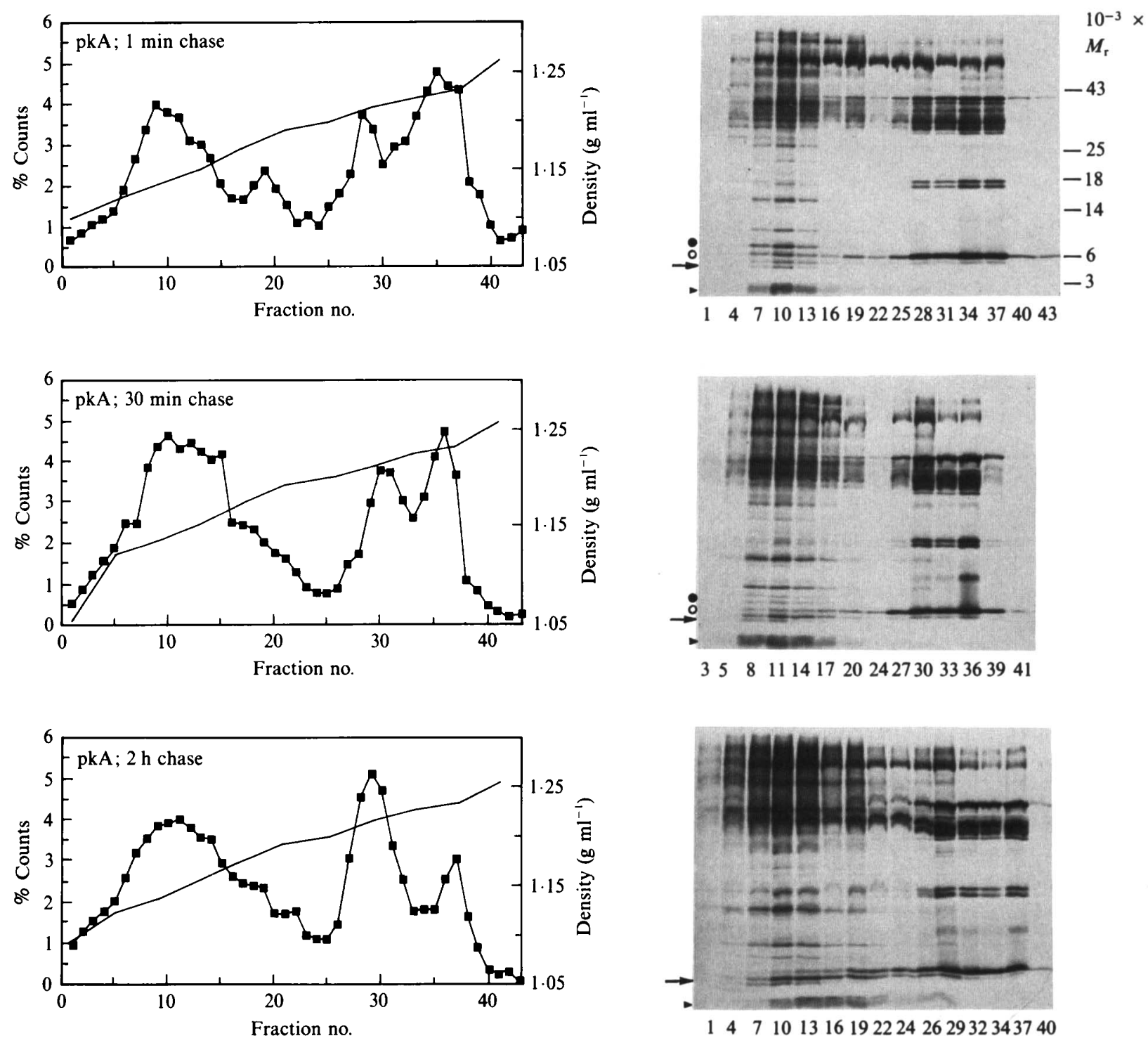

Fig. 4. Precursor and lipid-modified precursor $\mathrm{Cal}$ are found in the inner membrane while mature Cal fractionates with both inner and outer membranes. CBM $\operatorname{deg} P(\mathrm{pKA})$ cells were induced with mitomycin $\mathrm{C}$ and after a further 45 min incubation, pulsed with ${ }^{[35}$ S]methionine $\left(370 \mathrm{kBq} \mathrm{ml}^{-1}\right)$ for $5 \mathrm{~min}$ and chased with unlabelled methionine. After the periods of chase indicated, the cells were harvested and disrupted. The envelope was isolated and the inner and outer membranes fractionated on a $20-60 \%$ sucrose density gradient. The radioactivity $(\boldsymbol{\sigma})$ and density $(-)$ profiles of the gradients are shown at the left. The indicated fractions were electrophoresed on urea/SDS-PAGE gels, the fluorograms of which are shown on the right. $\bigcirc$, Position of precursor Cal; $\boldsymbol{O}$, position of lipid-modified precursor $\mathrm{Cal} ; \rightarrow$, position of mature $\mathrm{Cal} ; \rightarrow$, position of the signal peptide of $\mathrm{Cal}$

\section{Pulse-chase analysis of the localization and assembly of Cal}

The results shown above indicated that although tolQ cells no longer require activation of phospholipase $A$ for quasi-lysis and colicin $\mathrm{A}$ release, they do require the presence of a functional Cal protein. This further suggests that $\mathrm{Cal}$ in some way damages the envelope of the cell, and especially the inner membrane, in a manner independent of phospholipase A activation. As a first step in the direct analysis of Cal-induced membrane damage, we determined where within the envelope $\mathrm{Cal}$ is assembled and accumulated upon its induction in colicinogenic cells. Cells containing pKA were induced with mitomycin $\mathrm{C}$ and labelled with ${ }^{[35}$ S $]$ methionine, after which they were disrupted and their envelopes fractionated by isopycnic sucrose density gradient centrifugation. Because we had previously observed that 
the processing of Cal is exceedingly slow (Cavard et al., 1987; Howard et al., 1989), we also sought to observe Cal assembly intermediates directly within the membranes of the cell, and so incorporated a chase of varying periods of time in the protocol used to label the induced cells (see Methods). In order to avoid both the degradation of $\mathrm{Cal}$ caused by the $\operatorname{deg} P$ gene product (Cavard et al., 1989a) and possible artefacts caused by the accumulation of lysophospholipids in the cell envelope, we used CBM $\operatorname{degP41}$ cells for these experiments.

The results of this analysis performed on cells containing pKA are shown in Fig. 4. The rapid cooling, and centrifugation of the cell envelopes at $4{ }^{\circ} \mathrm{C}$ allowed us to fractionate membrane fragments containing the precursor, lipid-modified precursor, mature form and even the presumptive signal peptide of $\mathrm{Cal}$ as the protein was being processed and assembled in the envelope. The various forms of Cal were identified as before (Cavard et $a l ., 1987)$, by position of migration and comparison with uninduced cells. After a pulse of $5 \mathrm{~min}$ and chase of $1 \mathrm{~min}$, a significant amount of the $\mathrm{Cal}$ was still in the precursor form ( $\mathrm{pCal})$. Large amounts fractionated with the inner membrane, in which it was easily observed; however, due to the presence of the major lipoprotein, with which pCal comigrates, we could not determine whether any of the precursor $\mathrm{Cal}$ fractionated with the outer membrane. The major form of Cal present at this time was lipid-modified precursor, and this fractionated with the inner membrane. At this time, only a small amount of mature Cal was present, but it appeared to have rapidly migrated throughout the envelope, so that it was present in both inner and outer membrane fractions of the gradient, in amounts which appeared to correlate with the amount of membrane protein present. The presumptive signal peptide could also be observed, and it too was widely distributed across the gradient, but it appeared to be slightly more restricted in its mobility within the envelope, so that the majority fractionated with the inner membrane. After 30 min of chase, only small amounts of precursor and lipid-modified precursor could be observed, again in the inner membrane fractions. Large amounts of mature $\mathrm{Cal}$ and the signal peptide were present, however, with $\mathrm{Cal}$ again fractionating with both membranes, while the signal peptide was almost entirely localized in the inner membrane. The latter two products, with the same distributions, were the only forms which could be reliably observed after $2 \mathrm{~h}$ of chase. No trace of the lipid-modified precursor could be observed in either membrane at this time, and no precursor could be observed in the inner membrane fractions. The migration of the mature form of the major lipoprotein to this position on the gels again made it difficult to verify the presence or absence of precursor $\mathrm{Cal}$ in the outer membrane fractions.

\section{Effects of Cal induction on the fractionation of inner and outer membranes}

In addition to the processing and assembly of $\mathrm{Cal}$ which we were able to observe on these gradients, the distribution of the membrane proteins themselves appeared to vary with increasing time of induction of the colicin operon. For the sample which had been chased for $1 \mathrm{~min}$ following the pulse before being fractionated, which represents $51 \mathrm{~min}$ of induction, the four major membrane peaks of IM, B, OM $\mathrm{L}_{\mathrm{L}}$ and $\mathrm{OM}_{\mathrm{H}}$ as designated by Ishidate et al. (1986) were observed, with IM and $\mathrm{OM}_{\mathrm{H}}$, of densities $1.14 \mathrm{~g} \mathrm{ml}^{-1}$ and $1.23 \mathrm{~g} \mathrm{ml}^{-1}$ respectively, representing the largest peaks (Fig. 4). With increasing time of incubation, however, there was a noticeable shift in the density at which the outer membrane material fractionated, such that after $1 \mathrm{~h}$ $20 \mathrm{~min}$ of induction ( $30 \mathrm{~min}$ chase) the $\mathrm{OM}_{\mathrm{L}}$ and $\mathrm{OM}_{\mathrm{H}}$ peaks were of almost equal size, and after $2 \mathrm{~h} 50 \mathrm{~min}$ induction $\left(2 \mathrm{~h}\right.$ chase) the $\mathrm{OM}_{\mathrm{L}}$ peak with a density of $1.215 \mathrm{~g} \mathrm{ml}^{-1}$ contained the majority of the outer membrane material. In addition it appeared that at this time the inner membrane peak had become more rounded and spread farther into the centre of the gradient. This redistribution was also evident on the urea/SDS gels, in which more membrane protein bands could be seen in the centre fractions of the gradients with increasing time of induction.

The experiments described above suggested that $\mathrm{Cal}$ induction could alter the structure of the envelope such that the densities of the various membrane fractions were changed. It should be noted, however, that it has previously been reported that the relative amounts of the various membrane peaks fractionated on these gradients can vary from preparation to preparation (Ishidate $e t$ al., 1986), and we too occasionally found variations similar to those shown in Fig. 4 even in the gradient profiles of control cells (not shown). Therefore in order to substantiate these perceived effects and to verify that they were due to Cal rather than colicin A, we performed similar experiments with cells which contained pAT. This plasmid is similar to pKA but has a large deletion of the colicin $\mathrm{A}$ operon which results in the production of an inactive $20 \mathrm{kDa}$ fragment of colicin A and the strong overproduction of Cal (Cavard et al., 1989b). As before, the cells were induced with mitomycin $C$ and after 45 min labelled for 5 min with ${ }^{35}$ S]methionine. After a further $2 \mathrm{~h}$ incubation, they were disrupted and their envelopes fractionated (Fig. 5). In this case the separation between inner and outer membrane peaks was very poor, despite the fact that the density profile of the gradient itself was identical to that of the previous gradients. The apparent densities of the partially merged inner and outer membrane peaks were 1.17 and 

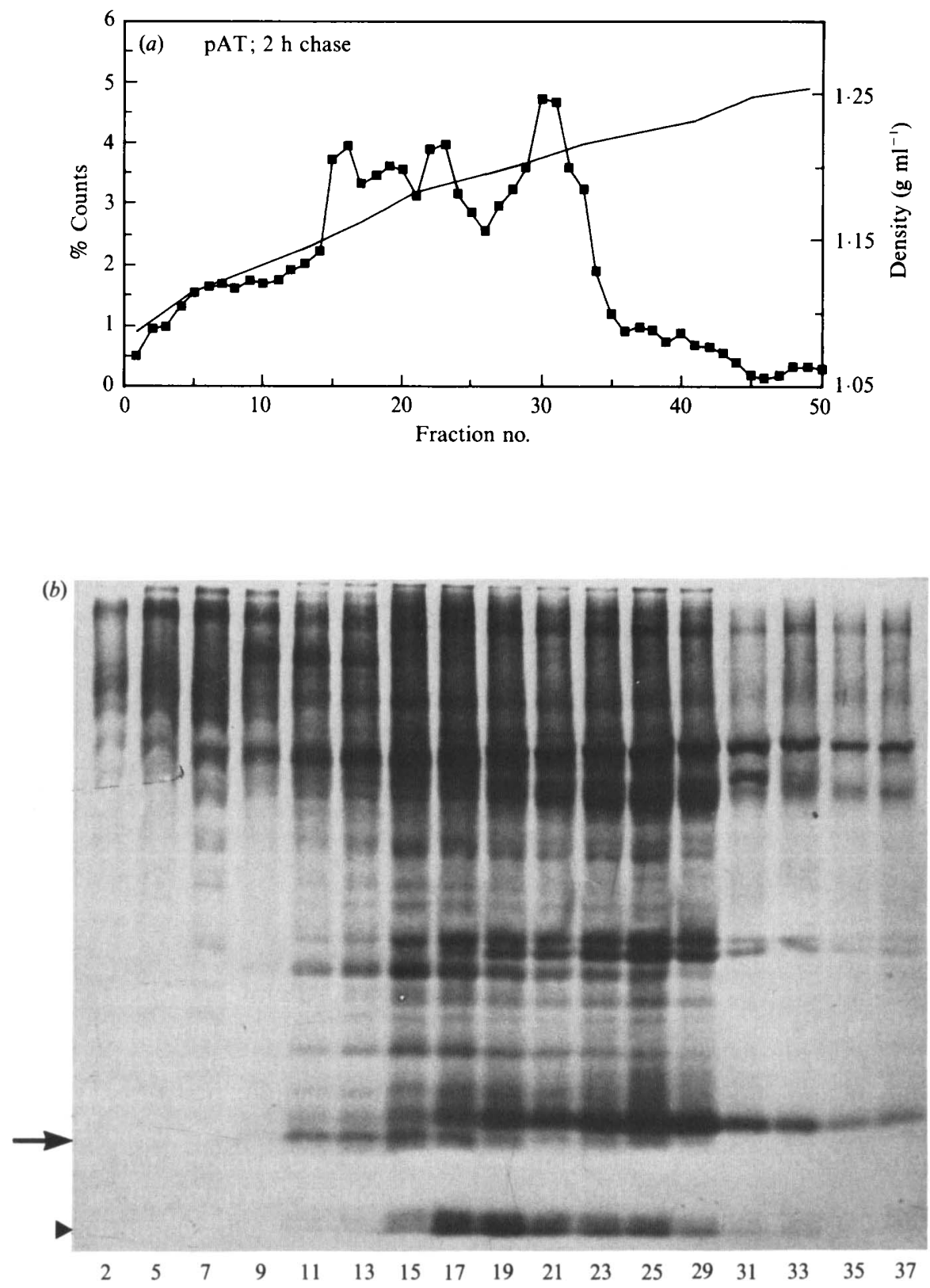

Fig. 5. High-level synthesis of $\mathrm{Cal}$ results in poor separation of the inner and outer membranes on sucrose density gradients. CBM $\operatorname{deg} P(\mathrm{pAT})$ cells were induced with mitomycin $\mathrm{C}$ and after a further 45 min incubation, pulsed with $\left[{ }^{35}\right.$ S $]$ methionine $\left(370 \mathrm{kBq} \mathrm{ml}^{-1}\right)$ for $5 \mathrm{~min}$ and chased with unlabelled methionine. After a further $2 \mathrm{~h}$ incubation the membranes were isolated and fractionated on a sucrose gradient. (a) Radioactivity ( $\boldsymbol{(})$ and density $(-)$ profile. (b) Fluorogram of the urea/SDS-PAGE gel of the indicated fractions. The positions of mature Cal $(\rightarrow)$ and the signal peptide $(\rightarrow)$ are shown.

$1.21 \mathrm{~g} \mathrm{ml}^{-1}$ respectively. The poor separation was also very evident from the fluorogram of the urea/SDS gel, which shows substantial trailing of all of the major protein bands of the two membranes into the centre fractions of the gradient. Among these both mature Cal and the signal peptide could be observed, both fractionating essentially throughout the gradient.

\section{Discussion}

In previous studies of $\mathrm{Cal}$, we demonstrated that it is responsible for the release of colicin $A$ and a large number of other soluble proteins of the cell during the quasi-lysis of the culture which follows its induction (Baty et al., 1987). In addition, as for colicin E2 and 
cloacin DF13 release (Pugsley \& Schwartz, 1984; Luirink et al., 1986), it was shown that if the colicinogenic cells contained a pldA mutation, colicin release, quasi-lysis and cell death were sharply reduced (Cavard et al., 1987, $1989 c$ ). These effects were never completely abolished, however, suggesting that the major function of $\mathrm{Cal}$ in colicin release is not simply to activate this phospholipase.

Our study of the leakage of proteins from tolQ cells showed that, as for the tolA and tolB mutants (FogniniLefebvre et al., 1987), the absence of the tolQ protein disrupts the organization of the cell envelope such that the outer membrane becomes permeable for periplasmic proteins. In these cells, therefore, we could specifically examine the passage of colicin A across the inner membrane. The results shown in Figs 2 and 3 demonstrated that the requirement for phopholipase A activation for colicin release, but not the requirement for $\mathrm{Cal}$, is bypassed in the tol $Q$ cells. This suggests that $\mathrm{Cal}$ damages the envelope independently of phospholipase $A$ activation, which appears to be required specifically for the breach of the outer membrane permeability barrier.

In order to learn more about how Cal permeabilizes the envelope, we began by looking at the localization and assembly of Cal in the membranes. We had previously observed that the processing of this small lipoprotein is slow, and that small amounts of mature $\mathrm{Cal}$ are released to the culture supernatant during colicin release (Cavard et al., 1985, 1987; Howard et al., 1989). By using pulsechase labelling followed by fractionation, we have now shown that in fact the lipid modification and processing of precursor $\mathrm{Cal}$ are so slow that its membrane-bound assembly intermediates can be fractionated by centrifugation in sucrose density gradients. The results indicated that precursor, lipid-modified precursor, and mature $\mathrm{Cal}$ are found in the inner membrane, while mature Cal but not lipid-modified precursor $\mathrm{Cal}$ is found in the outer membrane. Even the presumptive signal peptide could be observed on these gradients, and it too was restricted in its distribution relative to that of Cal. In fact, the results suggest that all forms of $\mathrm{Cal}$ which contain the signal sequence, and indeed the signal peptide itself, are restricted to the inner membrane fractions, whereas mature $\mathrm{Cal}$ is apparently assembled into both membranes. It is interesting to note that appreciable quantities of both lipid-modified precursor and the signal peptide can be seen in the early fractions of the outer membrane region of the gradient but then abruptly disappear from the later fractions (i.e. both are easily visible in fraction no. 28 of the 1 min chase sample shown in Fig. 4 but neither can be seen in fraction no. 31, and the last fractions in which the signal peptide is visible after $30 \mathrm{~min}$ and $2 \mathrm{~h}$ of chase are nos 30 and 29 , respectively). It is this region of the gradient which contains the boundary between the $\mathrm{OM}_{\mathrm{L}}$ fraction, which was shown to be a mixture of inner and outer membrane components (Ishidate et al., 1986), and $\mathrm{OM}_{\mathrm{H}}$, the true outer membrane fraction. Thus their presence in this 'outer membrane' region of the gradient does not contradict the interpretation that they are restricted in distribution to the inner membrane.

The mature cloacin DF13 and colicin E2 lysis proteins were also found in both inner and outer membranes (Cole et al., 1985; Hakkaart et al., 1981; Oudega et al., 1984). The colicin $\mathbf{N}$ lysis protein was found only in the outer membrane, however, when pld $A$ cells which were carrying a colicin $\mathbf{N}$ plasmid were examined (Pugsley, 1988). While it was suggested that this difference may have been due to the effects of phospholipase A activation in the wild-type cells, our results do not substantiate this, since we found Cal to be distributed in both membranes whether or not the cells carried the pldA mutation (Fig. 4 and data not shown).

An explanation for the longevity of the Cal assembly intermediates remains elusive;. We have recently shown that the processing of tuncated forms of $\mathrm{Cal}$ is inhibited, apparently due to their short length, since replacement of the missing segment with random sequence restored processing (Howard et al., 1989). We could thus imagine that whatever component of the lipoprotein secretion machinery which is sensitive to the short length of the truncated forms is in fact already inhibited by the short length of the wild-type Cal precursor (51 amino acids). Such an explanation could not, however, easily explain the stability of the signal sequence once cleaved from the protein. Although as previously shown the $\operatorname{deg} P$ mutation results in increased stability of lipid-modified precursor $\mathrm{Cal}$, it has no effect on the signal sequence, since it accumulates in both $\operatorname{deg} P$ and wild-type cells (Cavard et al., 1989a). In vitro mutagenesis studies are in progress to determine which structural features of the precursor are responsible for its stability.

The gradient fractionation experiments demonstrated that under conditions of overproduction, Cal caused large alterations in the apparent densities of the inner and outer membranes, such that they were no longer separated on sucrose density gradients. These changes did not depend on the activation of phospholipase $A$ which Cal is known to cause, since the experiments were done with pldA cells. Given the small size and amphiphilic nature of $\mathrm{Cal}$, which may in fact be viewed as a lipopeptide, it is tempting to speculate that its function involves a physical disturbance of the membranes, perhaps leading to regions of non-bilayer structure. It is interesting to note that studies on iturin A and other fungicidal lipopeptides have shown that their activity depends upon the attainment of a critical concentration (Besson et al., 1990), which in the case of 
iturin A corresponds to its critical micellar concentration (Harbois et al., 1990). Studies with strains which overproduce Cal suggested that it too acts when a critical concentration has been reached (Cavard et al., 1989b). If this is the case, it is possible that the effects of divalent cations in inhibiting quasi-lysis (Cavard et al., 1989c; Pugsley \& Schwartz, 1984; de Graaf \& Oudega, 1986) and of Triton X-100 in promoting it (Cavard et al., $1989 c$; Pugsley \& Schwartz, 1984) may be due to alterations in the membrane which would change the critical concentration of Cal required for the membranedamaging event. A fundamental disturbance of envelope structure might also be reflected in an inability to normally separate the two membranes, as we found here. In any case we have shown that density gradient analysis of the envelope of cells which are producing Cal allows direct observation of damage to the membranes which is independent of phospholipase activity. Further studies are required in order to understand the precise nature of this damage.

This work was supported by research grant MT10470 to S.P.H. from the Medical Research Council of Canada and by funds provided by Centre National de la Recherche Scientifique. The technical assistance of Bo Jiang is gratefully acknowledged.

\section{References}

Baty, D., Lloubes, R., Geli, V., Lazdunski, C. \& Howard, S. P. (1987). Extracellular release of colicin A is non-specific. EMBO Journal 6, 2463-2468.

Bernstein, A., Rolfe, B. \& OnOdera, K. (1972). Pleiotropic properties and genetic organization of the tolA,B locus of Escherichia coli K-12. Journal of Bacteriology 112, 74-83.

Besson, F., Peypoux, F. \& Michel, G. (1990). Antifungal activity upon Saccharomyces cerevisiae of iturin A, mycosubtilin, bacillomycin and their derivatives: inhibition of this antifungal activity by lipid antagonists. Journal of Antibiotics 32, 828-833.

Bourdineaud, J.-P., Howard, S. P. \& LAZDUNSKI, C. (1989). Localization and assembly into the Escherichia coli envelope of a protein required for entry of colicin A. Journal of Bacteriology 171, 2458-2465.

Cavard, D., Lloubes, R., Morlon, J., Chartier, M. \& Lazdunski, C. (1985). Lysis protein encoded by plasmid ColA-CA31. Gene sequence and export. Molecular and General Genetics 199, 95-100.

CaVard, D., Baty, D., Howard, S. P., Verheji, H. M. \& LAZDUNSKI, C. (1987). Lipoprotein nature of the colicin A lysis protein: effect of amino acid substitutions at the site of modification and processing. Journal of Bacteriology 169, 2187-2194.

CAVARD, D., LAZDUNSKI, C. \& HowaRD, S. P. (1989a). The acylated precursor form of the colicin A lysis protein is a natural substrate of the DegP protease. Journal of Bacteriology 171, 6316-6322.

Cavard, D., Howard, S. P., Lloubes, R. \& Lazdunski, C. (1989b). High-level expression of colicin A lysis protein. Molecular and General Genetics 519, 217-519.

Cavard, D., Howard, S. P. \& Lazdunski, C. (1989c). Functioning of the colicin A lysis protein is affected by Triton X-100, divalent cations and EDTA. Journal of General Microbiology 135, 1715-1726.

Cole, S. T., Saint-Joanes, B. \& Pugsley, A. P. (1985). Molecular characterization of the colicin E2 operon and identification of its products. Molecular and General Genetics 198, 465-472.

Fognini-Lefebvre, N., Lazzaroni, J. C. \& Portalier, R. (1987).
tolA, tol $\mathrm{B}$ and excC, three cistrons involved in the control of pleiotropic release of periplasmic proteins by Escherichia coli K12. Molecular and General Genetics 209, 391-395.

De Granf, F. K. \& Oudega, B. (1986). Production and release of cloacin DF13 and related colicins. Current Topics in Microbiology and Immunology 125, 183-205.

Hakkaart, M. J. J., Veltkamp, E. \& NiJkamp, H. J. J. (1981). Protein $\mathrm{H}$ encoded by plasmid CloDF13 involved in lysis of the bacterial host. I. Localisation of the gene and identification and subcellular localisation of the gene $\mathrm{H}$ product. Molecular and General Genetics 183, 318-325.

Harbois, I., Maget-Dana, R. \& Ptak, M. (1990). Amphiphilic properties of bacterial lipopeptides: self-association and monolayer studies of iturins. Journal of Colloid Interface Science 123, 85-91.

Heller, K. J., KadNER, R. J. \& GUNTHER, K. (1988). Suppression of the btuB451 mutation in the ton $\mathrm{B}$ gene suggests a direct interaction between TonB and TonB-dependent receptor proteins in the outer membrane of Escherichia coli. gene 64, 147-153.

Howard, S. P. \& BuCKLEY, J. T. (1985). Protein export by a gramnegative bacterium: production of aerolysin by Aeromonas hydrophila. Journal of Bacteriology 161, 1118-1124.

Howard, S. P., Cavard, D. \& Lazdunski, C. (1989). Amino acid sequence and length requirements for assembly and function of the colicin A lysis protein. Journal of Bacteriology 171, 410-418.

Ishidate, K., Cregger, E. S., Zrike, J., Deb, S., Glauner, B., MCALISTER, T. J. \& ROTHFIELD, L. (1986). Isolation of differentiated membrane domains from Escherichia coli and Salmonella typhimurium, including a fraction containing attachment sites between the inner and outer membranes and the murein skeleton of the cell envelope. Journal of Biological Chemistry 261, 428-443.

Lazzaroni, J. C. \& Portalier, R. C. (1981). Genetic and biochemical characterization of periplasmic-leaky mutants of Escherichia coli K-12. Journal of Bacteriology 145, 1351-1358.

Luirink, J., Van Der Sande, C., Tommassen, J., VeltKamp, E., de GRAAF, F. K. \& OUDEGA, B. (1986). Effects of divalent cations and of phospholipase A activity on excretion of cloacin EF13 and lysis of host cells. Journal of General Microbiology 132, 825-834.

NAGEL DEL ZWAIG, R. \& LURIA, S. E. (1967). Genetics and physiology of colicin-tolerant mutants of Escherichia coli. Journal of Bacteriology 94, 1112-1123.

NOMURA, M. \& WITTEN, C. (1967). Interactions of colicins with bacterial cells. III. Colicin-tolerant mutations in Escherichia coli. Journal of Bacteriology 241, 3055-3062.

Oudega, B., Ykema, A., Stegehuis, F. \& de GraAf, F. K. (1984). Detection and subcellular localization of mature protein $\mathrm{H}$ involved in excretion of cloacin DF13. FEMS Microbiology Letters 22, 101-108.

PugsLeY, A. P. (1988). The immunity and lysis genes of ColN plasmid pCHAP4. Molecular and General Genetics 211, 335-341.

PUGSLeY, A. P. \& SchWARTZ, M. (1983). Expression of a gene in a 400base-pair fragment of colicin plasmid ColE-P9 is sufficient to cause host cell lysis. Journal of Bacteriology 156, 109-114.

Pugsley, A. P. \& SchwarTZ, M. (1984). Colicin E2 release: lysis, leakage or secretion? Possible role of a phospholipase. EMBO Journal 3, 2393-2397.

SUN, T. P. \& WEBSTER, R. E. (1986). fii, a bacterial locus required for filamentous phage infection and its relation to colicin-tolerant tolA and tolB. Journal of Bacteriology 165, 107-115.

SUN, T. P. \& WEBSTER, R. E. (1987). Nucleotide sequence of a gene cluster involved in the entry of the E colicins and the single-stranded DNA of infecting filamentous phage into Escherichia coli. Journal of Bacteriology 169, 2667-2674.

Watson, R. J., Lau, P. C. K., Vernet, T. \& Visentin, L. P. (1986). Characterization and nucleotide sequence of a colicin-release gene in the hic region of plasmid ColE3-CA38. Gene 42, 351-355.

Yamada, M., Miki, T. \& NakazaWA, A. (1982). Translocation of colicin E1 through cytoplasmic membrane of Escherichia coli. FEBS Letters 150, 465-468.

Yamato, I., ANRaku, Y. \& Hirosawa, K. (1975). Cytoplasmic membrane vesicles of Escherichia coli. I. A simple method for preparing the cytoplasmic and outer membranes. Journal of Biochemistry 77, 705-718. 